\title{
DISPOSABLE COMMENSALITY: STRATEGIES FOR THE SELECTION OF MEALS IN THE OFFICE
}

\author{
Mg. Aldana Boragnio \\ Argentina \\ National Council of Scientific and Technical Research (CONICET) \\ Research Institute Gino Germani (IIGG) \\ Universidad de Buenos Aires (UBA) \\ Viamonte 430, Buenos Aires, Pcia de Buenos Aires, Argentina, B1053 \\ boragnio@gmail.com
}

\begin{abstract}
In order to understand the act of eating it becomes necessary to place it within a determinate society, time and space, which are structured by concrete practices and organized by specific rules and norms. Knowledge about food consumption within the working space is relevant because the food practices deployed during office hours are linked to the relation between energy use and the replenishment of energies necessaries for the working tasks.

These strategies of selection of meals by the women interviewed were organized in the articulation between the available physical space, the body and the available time for eating. These women seek to eat in the fastest time possible and therefore consume "fast food" and "light" food. At this way, a "disposable commensality" is structured as a way of everyday eating in the office, where the relation heavy/fast organizes the food practices in contrast to the body used as a recipient.

The data for this article is part of a wider research in which I seek to describe the everyday eating practices of working women within the spaces of national public offices, in relation to their eating and commensality. The article begins with (a) the exposition of the bases connecting bodies/emotions with eating; b) present the meals selected daily and the strategies for the selections of these meals as explained by the women and c) d) explain the relation between food/body/space.
\end{abstract}

Keywords: food practices, eating practices, commensality, body, emotions.

\section{Introduction}

In order to understand why we eat what we eat we need analytically discern its praxis and place it within a determinate society, time and place; structured by concrete practices and organized by specific rules and norms.

When we study topics related to the eating of urban populations, it is necessary to add approaches that go beyond economic possibilities or the taste the people that eat. Understanding the consumption of food in the work place, for example, is very important because the food practices during work periods are directly linked to the relation between energy expenditure and the replenishment of energy needed for specific tasks.

In cities, food practices are enacted in a context filled with specificities which must be taken into account. While these aspects mark access at a macro level, we must also consider the level of the subject's strategies in relation to the frame of relations produced by different commensalities.

The data presented here are part of an exploratory research project by which we seek to describe the everyday eating practices of working women in the labor sphere of public offices in Argentina.

We carried out in-depth interviews with 12 women employed in the National Secretariat of the Social Development Ministry of Argentina. The women were ages between 22 and 56 years and with labor seniority in the Ministry spanning of between 6 months and 23 years. We stablished three specific groups:

1) "administrative" women working in administrative posts;

2) "professionals", who have completed university degrees and work in areas related to their profession;

3) "young", women with less than thirty years of age in either administrative or professional tasks, without children and living independently. 
In this article we will:

a) expose the bases connecting bodies/emotions with eating;

b) briefly describe the theme of eating;

c) present the meals selected daily and the strategies for the selections of these meals as explained by the women interviewed;

d) explain the relation between food/body/space.

The aim of this article is to present the axes of relationship between food, body and space, based on the selection strategies of the women interviewed.

\section{Bodies, emotions and food}

When we speak of eating we speak of bodies: bodies that eat and bodies that are formed by food.

Here, we consider the body form the perspectives of three interrelated levels of analysis: the individual body, the subjective body, and the social body.

A body individual, which refers to a phylogenetic logic, to an articulation between the organic and the environment; a body subjective, configured by self-reflection, in the sense of a "self" as a center of gravity of the interweaving and transit of multiple subjectivities and, finally, a body social, which is (in principle) the embodied social fact (in Bourdieu's sense) [1, p. 185].

The individual dimension refers to the body as a biological organism, in the sense that it possesses genetically constituted organs, functions and processes. The subjective level is to be found in the field of the "self", which constructs a narrative of its own existence as a biography. In the world, interactions and relations with others take center stage in the construction of this biography. Lastly, the social level embodies learning, practices, and habits shaping the body and constitutes the subjectivity stemming from socialization.

By placing the body in relation to the characterization of the different types of hunger stablished by De Castro [2], we find a proposal for the conceptualization of hunger from a sociological perspective, emphasizing its relational character.

Individual hunger refers to the "lack of nutrients" experienced by the individual body at the biological level (socially understood). It refers to the absence of nutrients (in a broad sense) for the reproduction of that body. It is enacted at the level of the relations between individuals, social organizations, and the environment. Subjective hunger affects the "auto-reflexivity of the self", i. e. it links the consequences of "identity" order, in the cognitive sphere which are related to hunger. It is enacted in the field of the relations of the human being with himself and its consequences in the embodied self-image of the subjects. Social hunger has an impact in the social presentation of the subject [3, p. 67].

By understanding that the individual hunger refers to a relation between the human being-the environment, and that subjective hunger refers to the relation human-'self', social hunger articulates the two other levels in relation to the lived experience in society.

At this point it becomes necessary to stress that when we speak of the body there is no obvious way of separating it from emotions, because we know the world by, and through, the body. Therefore, form these conceptualizations, we understand hunger as a core life experience that, as such, structures emotions and sensibilities because it points to "the crossing points and the networks between bodies/emotions, given its social construction character, crossed by the consequences of the policies of the body and the policies of emotions" [4, p. 104].

It is important to note that the bodies are in connection with the surrounding/environment from processes given in the interaction between the brain/central nervous system/nutrients/energies, by which the unequal distribution of nutrients/energies model the potentialities of the states of possible life of the subjects as social agents [4]. In this sense we can distinguish between:

The body of appearance: how "I see myself as seen by others" in a determinate time and space; "is the image of society and the geometry of the bodies [which] alert of the place in which the body is inscribed ...The body of flesh: as 'naturally being' the world. It involves the senses as they appear as originally socially constructed, i. e. as a naturalized reference point for the sentiments and emotions as links indicating the regulation devices of the sensations... The body of movement: 
'an embodied inscription of the possibilities of [in]action. Social relations do not exist without bodies in action, which implies the consumption of sufficient energy for the production-reproduction of life" [5, p. 6].

In the current phase of capitalism -with worldwide characteristics of repression, extraction, and expropriation of the sum of the energies produced by human beings $[3,6,7]-$ the unequal appropriation and distribution of energy and nutrients affects the bodily energies.

When speaking of energy, experts usually refer to calories [8]. But when we use the concept of 'bodily energy' $[4,9,10]$, we are referring to a direct relation body/nutrients as "the result of the exchange between the physiological systems and the biological processes associated with the perdurability of the body individual" [10, p. 116]. Instead, social energy emerges from the relation nutrients/action, which is "based on bodily energy refers to its distribution processes as a substratum of the conditions of movement and action. The capacity to plan, execute, and solve the consequences of the action of the agents constitutes the social energy they possess" [10, p. 116].

Thus, the possibility and capacity to plan and execute movement and action will be conditioned by the availability of energy. As bodily energy is in direct relation to nutrients, without nutrients, there is no bodily energy, and the less nutrients, the less possibility of action. According to Scribano and De Sena:

If eating does not include the nutrients with sufficient and necessary energy value to allow the extension of life beyond the mere physical reproduction, there is a volume of this energy which is being expropriated and accumulated (and distributed) differentially (by some and for some) [10, p. 117].

If we consider that the availability of food resources alters the quantity and quality of energy at the disposal of each individual, giving those bodies their reproduction and social availability, it becomes essential to center on the "organic/cognitive/affective that joins the live force of the muscles with the creative/productive potentiality of the brain and its connections, which is central to the social structuration" [11, p. 33].

In this sense, eating is closely linked to the "possibilities of the social presentation of the person (body of appearance), the potentialities to experience the world (body of flesh) and the capacity to transit/do in the social world (body of movement)" [4, p. 104], these interactions being the indicators of social domination.

Thus, when we speak of eating we refer to the bodies/emotions that need basic nutrients for the production and reproduction of their embodied energies in order to "preserve the state of 'natural' things in systematic functioning". At the same time, social energy is constituted based on the embodied energy from the processes of distribution of the embodied energy as a condition for action.

\section{Materials and Methods}

\section{1. Studies on the Sociology of Food}

A considerable number of studies have attempted to conceptually delimit the sociocultural dimensions of eating. Norbert Elias [13], studied the modifications undergone by the everyday practices of the "civilization process", where the eating practices are among the most relevant, and are transformed from a set of precise norms and rules about "being around the table". Claude Fischler $[14,15]$ studied contemporary eating practices, analyzing the process of de-structuration of the culinary language and the individualization of the norms stablished in developed societies. Trying to understand todays conditioning of commensals through this modification and lack of norms, Fischler describes the paradox of the omnivorous and the principle of incorporation of eating, through which we incorporate nutrients as senses, which is at the core of eating because the commensal incorporates the material, but also the symbolic in his eating.

Goody [16] has sought to understand the relation between cooking and social class, stressing that "high" and "low" cuisine not only have different modes of combination and cooking meals, but also that they use different foods and products, which results in different class bodies.

Other authors have enquired about the eating changes of the so called "eating modernity" [17-19], to refer to the eating system that was formed in the industrialized society from the po- 
litical-social-economic changes since the sixties. This modernity is characterized by globalized, homogenized, industrialized, processed, de-structured, and individualized eating.

Ritzer [20], with his concept of "McDonaldization", focused on the process of rationalization behind the scientific organization of labor, the elimination of all waste of time, and on how these practices are reproduced in the whole of society, in labor processes and eating. While Mintz [21] has insisted in the importance of job opportunities as organizers of food practices of commensality during work hours.

Jesús Contreras Hernández and Mabel Garcia-Arnáiz [22], researching from an anthropological perspective, have considered eating in a broad sense, emphasizing socio-cultural behaviors, tastes and habits, the differentiated access to food, food safety, and eating as a bio-cultural phenomenon by which the biological organism needs food to function and at the same time food conditions the form and the illnesses of the bodies.

In Argentina, Patricia Aguirre [23-25], has worked from the perspective of anthropology of eating and done research on the strategies of consumption and eating differentiated by income and their outcome in terms of identity formation. She has also researched the formation of bodies by eating and the changes emerging in these bodies as a result of changes in food patterns, resulting in the current phenomenon of obesity and chronic illnesses -and the effect of theses in poverty levels [26, 27].

Martin Eynard [28, 29] has worked from the perspective of the sociology of bodies and socio-anthropology. He has analyzed collective actions and social protests asking for food in the period 2001-2007. These food conflict was taken over by the State, was not solved but mutated to less visible forms such as poverty related obesity, maleating, or what came to be called the "petisos sociales" - "petisos sociales" is understood in Argentinean Spanish as people of low height due to chronic maleating.

Lastly, research by Aguirre, Córdova, and Polischer [30] describe changes in the consideration of eating events as something lacking importance, in the sense of the decrease of common meals at home. As a result, the authors propose the existence of deregulated consumption which disintegrates local eating patterns, while increasing eating pathologies.

When we speak of eating we are referring to a practice by subjects which, in ideal conditions, must be repeated at least twice a day in order to replenish energies. In urban contexts the only possible access to food is through the market. Therefore, most subjects sell their labor force in order to earn a wage and buy foods; others have access to food via State assistance, but always inside the market as the regulator of exchange. Subjects that work in order to buy food face the paradox of having to work to eat, and eat to work.

\section{2. Eating and Working}

Eating at the work place is part of the rationalization process seeking normalization as the central axis of efficiency. The end goal of this process is the elimination of all loss of time [20], therefore, eating during work hours can be considered by employers - and even by workers themselves - as a "hindrance", or even as a "waste of time" or an unproductive time [31].

In the specific case of workers, eating during work hours is a basic need associated with available energy and cognitive capacities, vacant time, and the money needed to acquire food. At the same time, work conditions in relation to work hours, location of the work place, the structure of the facilities, and the type of activity, will also determinately influence the conditions and possibilities of eating for the workers [32].

It is important emphasize that eating during work hours, not only implies the issues mentioned above, but also includes the different ways in which the personal biography, tastes, selections, and commensality are enacted. Eating strategies, therefore, are played together with the relations and meanings through which these social places are differentiated.

In this sense, to speak of the eating practices of people who share a work place is not simply to describe different diets in relation to income. We need to observe that the triad "nutrition/malnutrition/existence constitutes the necessary adverse of the triad abstinence/waste/consumption" $[33$, p. 84$]$ which not only will hold different organizational positions according to how they come 
into play and how the distribution of nutrients and the commodification of the eating experience are enacted, but also the practice itself will be influenced by past experiences which, given their structural capacity, perform their own future [34].

Karl Marx, writing about the human organism, linked brain and muscles and referred to the connection between energy and work, presenting the body as a network of relations in which the connection expenditure/income must permanently reconstruct its own existence. Thus, energy, muscle capacity, body anchorage, and moral regime relation, are exposed in a relation in which exploitation and productive work will take place, producing in time "bodies-for-the-future" [11, p. 35].

From all of the above we can state that, supposing that the worker remains around a third of the day in his work place, eating and the time of eating in the work place is directly connected to the restoration of bodily energies and to the availability of these energies in the production process.

\section{2. 1. Meal selection strategies}

Without denying the fundamental economic variables that condition access to food, we should also consider that in everyday life subjects put into play their knowledge and creativity in their food practices. We will now consider those everyday food practices outside home, and the strategies to enact them.

Regarding the consumption strategies related to food, it is noteworthy that the characteristics most sought after follow representations and categorizations of the body pertaining to their aspects of strength, possibilities, and esthetic requirements. These strategies seek "satisfactors in eating", because food not only has a nutritional-biological value, it is also part of other uses, such as the principles of embodiment [14], sagacity, pleasure, identification and differentiation, ritual use, marker of time, etc. [23-25].

As we focus on the individuals that perform the selection strategies, it does not follow that we accept the notion of the individual of rational choice theory [35-38], instead we focus on the strategies expressed by the individuals in the process of selecting meals in the work space, while recognizing that these selections are not merely individual as, for example, they are also part of the consumption strategies of a family unit [39].

It is also important to note that the concept of selection marks action lines that produce meaningful, premeditated results of selection decisions based on available information and making use of resources in what the women interviewed consider the best for achieving their goals. Thus, when we approach the selection of meals in the everyday work space, we are not referring to a selection made from infinite possibilities, but a selection among alternatives, based on the evaluation of costs and benefits at short and medium range, of possible actions with the available information [25].

\section{2. What do they eat during the meal?}

In our interviews we found that salads, followed by sandwiches and cakes, lead the lunch time meals for working women at public administration work places.

Salads are consumed mostly as whole meals in themselves. Their composition varies, but for our interviewees the most common ingredients are: lettuce, tomatoes, carrots, diced cold pork, eggs, lentils, and rice. Among the young women interviewed we found a greater variety of ingredients, as they seek more "potent", filling, salads.

We later discovered a much better place, it was sort of naturist and had only salads, or mostly salads, the girl had several dishes, I don't know, they had arugula salad, spinach, Brussels sprouts, like... like more types of greens that made for more potent salads, and we ate that. (1 young - 27 years old).

All of the women interviewed said they ate salads during lunch time, as main or side dish. But we found some differences in the answers in relation to the job post and the way food was acquired.

Workers of the administration area, although often take salad for lunch, also add something bought something at nearby stores that sell food by weight. In these cases, the meal can include a 
salad and an empanada (small meat pie, usually made with a thin layer of dough, the filling is made of fatty meats, they can be baked or fried.), an omelet or a bun.

Some workers bring their lunch from home, or buy it from other workers that sell food inside the building. These workers usually have a main dish to which they add salad, or they add a protein - chicken or tuna - to the salad.

I generally bring my salad (...) But I always have lettuce, tomato and a thin beef, or chicken, or rice, but rarely something different. (4 adm - 35 years old).

Workers at professional posts, instead, buy their food in stores nearby and have salad as sole dish.

The second most consumed food by the interviewees is sandwich. These can be made with sandwich bread or bun and most include ham -it may be industrially processed pork ham, of poor quality and high fat content.

The younger workers and those at professional posts add to their list at lunch time a tarta $-\mathrm{a}$ pie made with different fillings and baked-, usually filled with ham and cheese and in some cases with zucchini, chard or pumpkin.

Notably, sandwiches are rarely made at home but are bought at nearby stores.

To sum up, the "menu" during work hours of the women we interviewed includes: salads, sandwiches and tartas, but these meals must be understood as parts of a puzzle of food preferences according to different selections strategies.

\section{Results and Discussion}

\section{1. Why do they eat what they eat?}

Interviewed women said they eat salad, sandwiches, and tartas. The main explanation for these selections is because they are "fast" foods.

Nothing that needs a lot, but a lot of time to digest, it has to be fast food and easy to eat here. (2 prof- 38 years old).

In the office, available time for lunch not only determines the type of selection made, but also the process of buying and consumption itself. If there is no specific time in which to have lunch, then food must compel the minimum effort and time for acquiring and consuming it, and also for its "digestion".

Given that the meals selected by the women interviewed - salads, sandwiches, and tartas, do not demand a lot of energy for their consumption, but neither do they offer a lot of energy, it becomes evident that the restoration of energy will not happen correctly: the consumption serves the purpose of "not feeling hungry" without adequately replenishing energy.

When we speak of "not feeling hungry" we are referring to the sensation of "a filled tommy" [la panza cruje]. It is important to note that 'hidden hunger' [2] is not a state reached at once, but the result of a maleating process that has consequences in the short, medium, and long terms. In the short term, the body needs to intake nutrients necessary for the restoration of the energies consumed. These energies are not compensated; this means that if the necessary nutrients are not consumed to restore the energies during the day, it is not possible to "supply" them during the night. Thus, bodily energy is in direct relation to the energies and nutrients incorporated in the short and medium term [40, 41].

I usually don't eat that much because I don't feel too well afterwards, I feel uncomfortable, because I have to sit, then I have to commute and it, it makes me feel bad (...). I rather have a light lunch so I can feel better while doing things, working and then commuting home. (4 adm35 years old).

Women interviewed tell us that sleepiness, apathy, and a sensation of discomfort is the first thing they feel after lunch, this is related in terms of nutrients, to an excess in fat and carbohydrates which lead to a feeling of slow digestive process and to sleepiness; and at the same time to the insufficiency of nutrients which produces a feeling a tiredness of the body. Therefore, they look for a "light" meal so that the digestive process is fast and efforts can be focused on "doing things", be these things work tasks or to commute to work and back home. 
But the digestive process not only depends on what we eat, it is a physical process influenced by the type of food selected, its macro-nutrients, and the ways we enact the actual process of eating. Ayurvedic medicine, for example, is concerned with eating as part of a whole which ends with digestion and must start with an environment which has the necessary conditions for eating, cleanness and good smell, among others. It is also concerned with the relation of the state of mind of the commensal and the sensory environment and nerves in the digestive process [42]. The concept of lightness recalls its opposite, heaviness. Lightness is sought after in meals in order to control the body and to avoid making it "heavy". Noteworthy is, not only the many times that women interviewed mentioned seeking to avoid heaviness - which makes us thing that it point to a situation not easily avoidable -, but also how the light/heavy is part of the discourse that organizes "meal at the office".

The following diagram organizes what the interviewees said about this issue (Fig. 1).

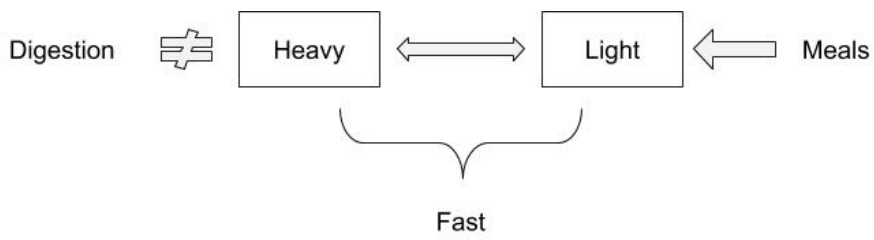

Fig. 1. Reasons why office meals. Source: prepared by the author

Heavy and light are linked by a double arrow to indicate they are both opposite sides of eating in the office. To avoid a heavy digestion we seek light meals. In this search for overcoming the relation heavy/light, fast foods reveal themselves as an alternative; they are fast to digest and therefore present themselves as the contrary to heaviness, and they can be consumed fast because of their format, which is also revealed as "fast food"; light in nutrients and therefore in bodily energy.

The triad heavy/light/fast are categories for the classification of meals, but they are also states of the body revealed by our interviewees in a specific space/time organized by "being in the office." These states of "the body in the office" are articulated by the speed of the minimum effort. Put differently, the aim is to be in the office feeling light and spending the least possible energy - energy which probably will not be restored- and this will have consequences for the available social energy.

To sum up: we note that in the selection of "meals in the office", women interviewed seek to include both the material and symbolic value of "lightness" to their choice, in counter position to the "heaviness" of being in the office.

\section{2. Meals, bodies, time, and space}

Office environment is a main dimension in the selection process of lunch meals. Office space can be limited, which sometimes does not allow for a designated space for eating.

If I have lunch at all, I usually have it on top of folders, or in a very intense environment, trying to hide so others don't see me, and besides; it's very complicated, more so in public administration, it's very difficult, you have to struggle because there not enough chairs, is you get to work with a computer, you're just there looking at the computer screen eating whatever they give you. If not, you try to move to a little corner, trying not to bother the others, the place is very small, very small, and I'm not very small, it's quite difficult to maneuver, or not? (2 young - 27 years old).

If eating is constituted from the social relations that make it possible [43], the fact that the architecture of the spaces lacks a place for eating, or that management does not consider it necessary to have such a designated space, takes us back to the links of eating/time/place.

Eating practices are the result of multiple social relations and cultural patterns which construct foods themselves and organize them in dishes, senses, and commensals. Time regulates the intake of food and organizes eating through socially stablished temporal sections which give sense to eating certain foods at certain times $[30,44]$.

Today, the "place" has lost its social organizations. With eight hours straight time shifts, eating practices are necessarily taken out of the private, domestic sphere, and into the public sphere. 
Starting from a historical process in which the social norms organizing the proper place for eating where progressively broken, we come to understand the phenomenon of "snacking" [18, 45-47], extended as a habit made possible by the flexibility of norms and the existence of products.

In order to problematize the connections eating/time/place revealed by the interviewees it is necessary to conceptualize the term "place". From an architectural and philosophical perspective [48], García Olvera writes that a place "is what determines the relation of a body with other bodies" [49], while Hidalgo Hermosilla tells us that "Heidegger will put in the forefront the different between place and space, by characterizing places as presences, things or constructions revealed as a mode of access to the relation between man and space" [50, p. 56]. And Milton Santos, form a geographical approach, defines place as "an object of series of objects" [51, p. 148].

Form the perspectives of anthropology and sociology, place has been an issue for several authors [52-56]. De Certeau:

A place is order (any order), according to which the elements are distributed in relations of coexistence. Thus, the excluded possibility of two things in the same place. (...) Place is, therefore, the instantaneous configuration of positions. It implies a sign of stability [56, p. 129].

We understand that a place refers to the combination of fixed elements in a place and to the relation between them, from which the subjects will be linked, enacting the social forces that configure the place as a space. In De Certeau [56, p. 129] words: "Space is a practiced place".

The relation place/space/practice is mutually constitutive. Eating space is formed from the material and symbolic limitations of the office space, and these limitations also structure the practices. The women interviewed do not have a place to eat, they also lack a regulated timeframe for eating, therefore the place - public administration offices - will fix the limits and, consequently, will condition the selection of meals.

These women take their lunch in an environment that does not allow for the conformation of an eating space. The office space is "very small", and the environment is "intense, complicated, difficult." Within these limits the interviewees try to dominate the space in order to set a time for eating, but the office space and the environment does not allow for this to happen. The office space stablish itself as a space for eating and the eating practices will be organize according to this space, therefore these women will eat very few, "very small", as the space allows.

If bodies exist in their relation to the environment, it becomes clear that women workers do not have control over it or over the things in it. They do not organize the moment of eating - not even the timeframe - instead, the objects organize the times: when there is a computer free, you work, when there is a chair, you sit, if there is place, you eat. Women workers struggle with these objects, with the space, "trying" to impose control and, in the best of cases, create a space where they are recognized as subjects of the space.

This leads to understanding the office space as a dimension that structures the practices of eating, where objects organize; women on the other hand, "struggle", "bother", have to settle for "a small corner", whatever is left over. That, which is "left over" from the place, is what is appropriated by those who are also "left over." In the following chart we organize what interviewed women say about their work space (Fig. 2).

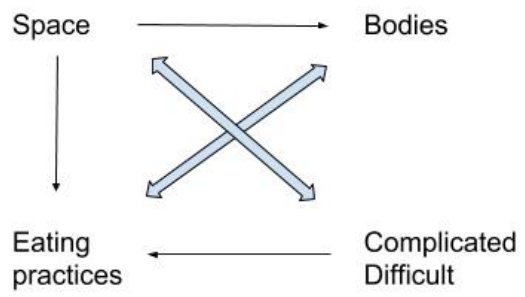

Fig. 2. Relation between office space and practices of eating. Source: Prepared by the author

Space is related to the complicated and difficult task of carrying on the tasks and practices for which that same space has been conformed, to the complications and the difficulty of actually being there. Eating practices are constituted from the space and in relation to its complicated and 
difficult character. Bodies therefore conform around this relation between space and eating practices, both as a resulting materiality of the practices and in relation to space.

We may now take into account the material conditions of the office space by considering that available facilities are factors that modify the selection of what to eat and how to eat it.

The office had different areas, but no walls, and everyone knew when you were going to eat. But sometimes you just couldn't, because there were important people hanging around, and you didn't feel comfortable, and people your same age also didn't'feel comfortable... Then you would have to get by with a piece of tarta, or mashed potatoes, because you didn't have an intimate space, and sometimes you feel ashamed that others see you eating and see what you are going to eat. (...) I don't know if the smell of the food bothers people, and I think that's something I feel all the time, and they may think "oh, she's eating", and the feeling is you are wasting your time instead of working. You're getting paid to come here to work and you are wasting your time eating. That's why I always have lunch in ten minutes. (1 young - 27 years old).

All the women we interviewed take lunch inside the office where they work. As we noted above, the environment can be intense, complicated, difficult, and does not provide for minimum dining facilities. At the same time, the number of people and the objects necessary for a lunch are also part of a lack of an adequate relation subject-space. In this context, shame emerges as the predominant emotion while eating in the office.

Shame emerges as a result of the perceived inconveniences caused to others because of the eating practices in a space that is not adequate for such practices. Scheler [55] claims that shame is a human feeling which emerges when one finds oneself placed in the middle of the connection between animals and God. Humans exist because and in their bodies, and the distance of this lived body and the spiritual body is the situation making possible the emergence of shame.

Scheler distinguishes modesty from shame. Modesty emerges from particularities which vary according to the historical moment, the region, gender, and age. But it becomes concrete in the particularity of each individual. Shame, on the other hand, is felt in the face of others, in the lived experience of the stare of the others, as an opposition of that which "should be" in a certain way and something which "is" different from what one is. In this sense, shame is understood as "feeling anticipating values" [57, p. 12].

Eating is stablished as a shared, everyday action, linked to domesticity [14], and its practices have specific rules which must be enacted from the outside. Eating is something usually done with others, not in front of others. But eating in front of others, when we use a space in a different way, leaves us in a situation of inadequacy between that space and the practices enacted in it. It also exposes us to the stare of others upon our life styles, our practices, our tastes, our social positions which are reflected in our ways of eating, what we eat, how we eat $[58,59]$ - and we are exposed to that stare marking the differences between what "should be" and what "is". Thus, shame emerges from putting into play our eating practices when the other is not eating, in a space that is inadequate for such activity.

Yet another axis is revealed in the interviews: time. Lunch is considered a waste of time because it is an unproductive moment of the day; it therefore has to be completed "in ten minutes." Recalling what we mentioned above, "fast" food (understood both as a type of food and as the time necessary for its consumption) is translated into the duration of the meal itself. The meal is done as fast as possible, trying to get back to work soon - even if at the moment the environment is complicated, intense, difficult, and with few "productive" possibilities.

We note that the selection of the meal and the moment of eating are influenced by the context and its material conditions, but these practices are enacted in a specific time-space. The offices these women work in do not have a designated space for eating, and the women themselves do not have a specific time in which they can eat. There is no such thing as a "lunch break", there is no time section to put order into the practices, or to put them into the order.

If you can, you have your own lunch box [tupper], your space, I mean, I have the desk, the computer and I'm sort of stuck there, and people come in, and the phone rings (...), there are people still working, there are people who don't eat, there is no common timetable for everyone. The people that are not eating go on asking you for things while you're chewing. (2 prof-38 years old). 
Without a timetable to organize eating practices, women interviewed are exposed to the "animal part" of our constitution: hunger. Therefore, eating in public produces shame because the other becomes a witness of our giving in to the physical imperative of hunger. In this context the practices of eating are made visible from the physical-organic, from the hunger that one wants to silence. Eating in public, without a timetable, the moment they feel hungry, interviewees are anchored in the animal-eating response, they therefore "hide", and they are "stuck", trying to stop others from "finding out" that they are "chewing".

Given these characteristic of the office, several interviewees stressed that they select their meals so that these not only adapt to time -fast- but also that they adapt to the environment: they must be simple, as clean as possible and that don't require silverware or can be eaten with.

...plastic cutlery, disposable. If you have to wash dishes here, there are no conditions here so everything has to be disposable. So if you finish eating everything has to go to the trash bin and everything has to remain squeaky clean, nobody ate here, nobody saw anything. (3 young28 years old).

If commensality is the way sharing meals assumes among humans, and its forms are articulated by the set of social relations that made possible the food becoming a meal; the rules of commensality are centered on the legitimate ways of sharing. The very few comforts at the work space, the lack of a place and a time for eating and of general facilities, are weaved into a type of commensality with can be labeled as "disposable commensality."

In worldwide capitalism, and specifically in the Global South, current political economy of morals are devoted to extending the depredation of energies to the sphere of everyday life, conforming "practices of feelings modeled from the disposable, what is disposed of, and of disposing as inter-action" [60, p. 110]. In this way, the structure of social relations in a society organized by a "Logic of Disposal" - from the interaction logics enacted between consumption and disposability extends its form to the connection with objects, to the interaction with other living beings, and to those living being themselves $[60,61]$.

What is disposable reveals itself between what is usable and what is not: In order to eat fast, we us disposable cutlery and plates which rapidly lead to the accomplishment of the goal of finishing the meal. We finish the meal and there is no need of washing the dishes. Moreover, the food consumed is also disposable and nutritionally useless, as is also the social practice, it must be dealt with fast. Food at the office is light (or heavy), fast, disposable, clean, one use only, hunger killer, and as such, once used it must be thrown in the trash bin. Food is thrown in the body in the same way it is thrown in the bin, and then "everything is made clean quickly, pretty, nobody ate, nobody saw anything," not even these working women did.

If practices do not restore energies nor reproduce the social, it is understandable that to enact them be considered as a "waste of time." Thus, we understand the practice of eating in the office as articulated in specific commensalities that result in a "disposable commensality", in which the heavy, the light, and the fast are forms of restoring energies, but without time or space for such a task.

\section{Conclusions}

1. By focusing on a specific space of the work sphere, we find that the labor condition at the offices of the National Public Administration, function, in relation of time/space, as organizer of strategies for the selection of meals.

These strategies of selection of meals by the women interviewed were organized in the articulation between the available physical space, its characteristics, and the available time for eating, by which these women seek to eat in the fastest time possible and therefore consume "fast food" and "light" food that allows them to alleviate the weight of the body itself.

2. Space and time constitute eating practices situated in the "complicated and difficult" place of having neither of the two. Thus, eating in the office is structured form the discomfort of eating fast, on top of the work desk, without space, time or timetable, and commensality in the office is organized under conditions of existence that are structured by those absences. Eating without a timetable for doing so, whenever possible and fast, does not allow for the social con- 
nections which emerge from eating practices. The selection of a meal is therefore articulated with a correspondence of subject/space from which the possibilities of planning the relations with the sociability of commensality and the restoration of energies which should be provided by eating during work become limited.

3. As stated by Marx, "the 'environment' of work is part of the conditions of existence, as much as they alter the senses by putting in-exposing the body of the worker to exploitation" $[33$, p. 33]. In this way, the triad heavy/light/fast organizes lunch through the search of a lightness articulated with the space, conforming this as a "complicated", "difficult" moment, which is only possible to overcome by turning bodies into recipients. A "disposable commensality" is structured as a way of everyday eating in the office, where the relation heavy/fast organizes eating practices in the search of "lightness" in contrast to the body used as a recipient of trash, turning the practice into a "disposable commensality".

Capital produces a "body-for-the-future" when the exploitation and expropriation of energy plus will take place. In this sense, the body individual, the body of flesh, and the body of movement will depend on the levels of consumption directly associated with the nutrients-food-hunger in a determinate time-space. This is why the observation of the ways in which the social energies of these work bodies, that eat fast, light, complicated, difficult, disposable, become available, is essential in order to understand the ways in which the policies of bodies mark the bodies/emotions and place them at the disposition of a reproduction which should allow them to "feel" (themselves) in a world through the body.

\section{References}

[1] Scribano, A. (2007). La sociedad hecha callo: conflictividad, dolor social y regulación de las sensaciones. Mapeando interiores. Cuerpo, conflicto y sensaciones. Córdoba: Jorge Sarmiento Editor.

[2] De Castro, J. (1962). Geopolítica del hambre. Ensayo sobre los problemas alimentarios y demográficos del mundo. Buenos Aires: Solar Hachette.

[3] Scribano, A., Eynard, M. (2011). Sociologando: Hambre individual, subjetivo y social (reflexiones alrededor de las aristas límite del cuerpo). Boletín Científico Sapiens Research, 1 (2), 65-69. Available at: https://www.researchgate.net/profile/Martin_Eynard/publication/222714102_Hambre_individual_subjetivo_y_social_reflexiones_alrededor_de_las_aristas_limite_del_cuerpo/links/02faf 4 f82dlbdeld1c000000/ Hambre-individual-subjetivo-y-social-reflexiones-alrededor-de-las-aristas-limite-del-cuerpo.pdf

[4] Scribano, A. (2012). Sociología de los cuerpos/emociones". Revista Latinoamericana de Estudios sobre Cuerpos, Emociones y Sociedad, 10 (4), 93-113. Available at: http://www.relaces.com.ar/index. php/relaces/article/viewFile/224/143

[5] Scribano, A.; Sarmiento, J. (Ed.) (2007). Salud, dinero y amor... ! Narraciones de estudiantes universitarios sobre el cuerpo y la salud. En Scribano A. (Comp). Policromía corporal. Cuerpos, grafías y sociedad, UNC- CEA/CONICET y Universidad de Guadalajara. Córdoba: Colección Acción Social.

[6] Scribano, A. (2011). Un bosquejo conceptual del estado actual de la sujeción colonial. SINAIS Revista Eletrônica - Ciências Sociais. Vitória: CCHN, UFES, 1 (9), 43-75.

[7] Quijano, A. (2000). Colonialidad del poder y clasificación social. Journal of World-Systems Research, 6 (2), 342-386. doi: http://doi.org/10.5195/jwsr.2000.228

[8] Glosario de terminos. Available at: http://www.fao.org/docrep/014/am401s/am401s07.pdf

[9] Scribano, A., Figari, C. (2009). A modo de epílogo ¿Por qué una mirada sociológica de los cuerpos y las emociones? Cuerpo(s), Subjetividad(es) y Conflicto(s). Hacia una sociología de los cuerpos y las emociones desde Latinoamérica. Buenos Aires: CICCUS.

[10] Scribano, A., De Sena, A. (2016). Cuerpos débiles: energías, políticas alimentarias y depredación de bienes comunes. Democracia, Pós-desenvolvimiento e gestão de benscomus. Perspectivas da América Latina e do Caribe. Brasil: Editora, 115-128.

[11] Scribano, A. (2016). Sociología de las emociones en Carlos Marx. Carolina del Norte: Editorial Contracorriente, 160 .

[12] Scribano, A. (2010). Primero hay que saber sufrir... !!!Hacia una sociología de la 'espera' como mecanismo de soportabilidad social. Sensibilidades en juego: miradas múltiples desde los estudios sociales de los cuerpos y las emociones. Córdoba: CEA. 
[13] Elias, N. (2009). El proceso de la civilización. México: Fondo de Cultura Económica.

[14] Fischler, C. (1995). El (h)omnívoro. El gusto, la cocina y el cuerpo. Barcelona: Anagrama, 421.

[15] Fischler, C. (2010). Gastro-nomía y gastro-anomía. Sabiduría del cuerpo y crisis biocultural de la alimentación moderna. Gazeta de Antropología, 26.

[16] Goody, J. (1995). Cocina, Cuisine y Clase: estudio de sociología comparada. México: Gedisa.

[17] Gracia-Arnáiz, M. (2003). Alimentación y cultura: ¿hacia un nuevo orden alimentario? Los modelos alimentarios a debate: la interdisciplinariedad de la alimentación, 205-230.

[18] Gracia-Arnaiz, M. (1997). Aproximaciones para explicar el cambio alimentario. Agricultura y sociedad, $82,153-182$.

[19] Contreras Hernandez, J. (2005). La modernidad alimentaria. Entre la sobreabundancia y la inseguridad. Revista Internacional de Sociología, 63 (40), 109-132. doi: http://doi.org/10.3989/ris.2005.i40.191

[20] Ritzer, G. (1996). La McDonalización de la sociedad. Un análisis de la racionalización en la vida cotidiana. Barcelona: Ariel.

[21] Mintz, S. (2003). Sabor a comida, sabor a libertad. Incursiones en la comida, la cultura y el pasado. Ediciones de la Reina. México, 174.

[22] Contreras Hernández, J., Gracia-Arnáiz, M. (2005). Alimentación y cultura: perspectivas antropológicas. Barcelona: Ariel.

[23] Aguirre, P. (1997). Patrón alimentario, estrategias de consumo e identidad en la Argentina, 1995. Procesos socioculturales y alimentación. Serie Antropológica. Ed. del Sol, Buenos Aires, 161-187.

[24] Aguirre, P. (2009). Comida y comensales. Representaciones acerca de los alimentos, la comida y el cuerpo en diferentes sectores de ingreso del AMBA. En Buscando señales. Lecturas sobre nuevos hábitos del Consumo Cultural. Córdoba: Centro Cultural España-Córdoba.

[25] Aguirre, P. (2005). Estrategias de consumo: qué comen los argentinos que comen. Argentina: Miño y Dávila.

[26] Aguirre, P. (2006). Los alimentos rendidores y el cuerpo de los pobres. Arbitrario cultural: racionalidad e irracionalidad del comportamiento comensal. Homenaje a Igor de Garine. Barcelona: La Val de Onsera.

[27] Aguirre, P. (2004). Ricos flacos y gordos pobres. La alimentación en crisis. Buenos Aires: Capital Intelectual.

[28] Eynard, M. (2014). Cuerpos, hambre y protesta social: la ocupación de un ministerio en demanda de alimentos. Revista Latinoamericana de Estudios sobre Cuerpos, Emociones y Sociedad, 14 (6), 54-67.

[29] Eynard, M. (2017). Cuerpos y alimentación en crisis: conflictos sociales en torno a la cuestión alimentaria en la ciudad de Córdoba, 2001-2007. Buenos Aires: Ese Editora.

[30] Gilardon, A., Enrique, O. (2015). Cocinar y comer en Argentina hoy. Buenos Aires: Fundasap y Sociedad Argentina de Pediatría, 264.

[31] Wanjek, C. (2005). Food at work. Workplace sollutions for malnutrition, obesity, and chronic diseases. Geneva. International Labour Office, 466.

[32] Ormazabal, J. (2008). Alimentación y trabajo. La Mutua, 20, 151-160.

[33] Scribano, A. (2013). Cuerpos y emociones en El Capital. Nómadas Colombia, 39, 29-45.

[34] Bertone, J., Eynard, M., Huergo, J., Lava, M. (2013). Un mundo de sensaciones: Las prácticas del comer entre el "placer" y el hambre. Paper presented at X Jornadas de Sociología de la UBA. Buenos Aires.

[35] Arrow, K. J. (1963). Social Choice and Individual Values. New York: John Wiley \& Sons, 124.

[36] Becker, G. (1976). The Economic Approach to Human Behavior. Chicago: University of Chicago Press, 314.

[37] Becker, G. (1987). Tratado sobre la familia. Madrid: Alianza, 366.

[38] Coleman, J. S. (1990). Foundations of Social Theory. Cambridge Belknap Press, 1014.

[39] Torrado, S. (1982). El enfoque de las estrategias familiares de vida en América Latina. Orientaciones teórico metodológicas. Buenos Aires: Cuaderno del CEUR, 2, 164.

[40] Brown, J. E. (2014). Nutrición en las diferentes etapas de la vida. México: McGraw Hill, 663.

[41] Uauy, R., Oyarzún, M. (2005). Análisis del caso de Chile en el informe FAO: estado sobre la inseguridad alimentaria en el mundo, 2004. Revista chilena de nutrición, 32 (3), 262-270. doi: http://doi.org/ $10.4067 / \mathrm{s} 0717-75182005000300012$ 
[42] Freidin, B., Ballesteros, M., Echeconea, M. (2013). En búsqueda del equilibrio: salud, bienestar y vida cotidiana entre seguidores del Ayurveda en Buenos Aires. Documento de trabajo No. 65. Instituto de Investigaciones Gino Germani.

[43] Aguirre, P. (2010). La construcción social del gusto en el comensal moderno. Comer. Puentes entre la alimentación y la cultura. Buenos Aires: Libros del Zorzal.

[44] Aguirre, P. (2017). Una historia social de la comida. Buenos Aires: Lugar Editorial, 376.

[45] Mintz, S. (1996). Dulzura y poder. El lugar del azúcar en la historia moderna. México: Siglo XXI Editores, 299.

[46] Poulain, J. P. (2002). Sociologies de I 'alimentation. Paris: Presses Universitaires de France.

[47] Díaz Méndez, C. (2005). Cómo comemos. Cambios en los comportamientos alimentarios en los españoles. Barcelona: Fundamentos.

[48] De Stefani, P. (2009). Reflexiones sobre los conceptos de espacio y lugar en la arquitectural del siglo XX. Revista Electrónica DU\&P. Diseño Urbano y Pasaje. Santiago, 16 (6).

[49] García Olvera, H. (2002). El concepto de lugar. Atajo, periodismo para pensar.

[50] Hidalgo Hermosilla, A. (2013). Los lugares espacian el espacio. Aisthesis, 54, 55-71. doi: http:// doi.org/10.4067/s0718-71812013000200003

[51] Santos, M. (2009). Espacio y método. Algunas reflexiones sobre el concepto de espacio. Gestión y Ambiente, 12 (1), 147-148.

[52] Kern, S. (1983). The Culture of Time and Space 1880-1918: with a New Preface. Cambridge: Harvard University Press, 372.

[53] Giddens, A.; Gregory, D., Urry, J. (Eds.) (1985). Time, Space and Regionalisation. Social Relations and Spatial Structures. London: Macmillan, 265-295. doi: http://doi.org/10.1007/978-1-349-27935-7_12

[54] Merrifield, A. (1993). Place and Space: A Lefebvrian Reconciliation. Transactions of the Institute of British Geographers, 18 (4), 516-531. doi: http://doi.org/10.2307/622564

[55] Bourdieu, P. (1999). Los efectos del lugar. La miseria del mundo. Barcelona: Akal.

[56] De Certeau, M. (1999). La invención de lo cotidiano. Vol. 1. Artes de hacer. México: Universidad Iberoamericana.

[57] Scheler, M. (2004). Sobre el pudor y el sentimiento de vergüenza. Salamanca: Sígueme, 157.

[58] Bourdieu, P. (1998). La distinción. Criterios y bases sociales del gusto. Madrid: Taurus, 597.

[59] Bourdieu, P. (2010). El sentido social del gusto. Elementos para una sociología de la cultura. Buenos Aires: Siglo Veintiuno Editores, 288.

[60] Scribano, A. (2015). ¡Disfrútalo! Una aproximación a la economía política de la moral desde el consumo. Ciudad Autónoma de Buenos Aires: Elaleph.com, 128.

[61] Scribano, A. (2017). Emociones y dependencias. Aportes a una sociología de los cuerpos y las emociones desde el sur. Ciudad Autónoma de Buenos Aires: Estudios Sociológicos Editora, 331-353. 